\title{
KEWENANGAN KOMISI PEMILIHAN UMUM DALAM MENETAPKAN PASANGAN CALON PRESIDEN DAN WAKIL PRESIDEN
}

\author{
M. Zainuddin $\mathrm{MZ}$ \\ Jl. Kolonel Sugiono Ngingas RT 02 RW 0 I Waru Sidoarjo | \\ dicky.fabercastell@gmail.com
}

\begin{abstract}
The General Election Commission (KPU) is national, permanent, and independent general election organizers. General election, which is held to elect members DPR, DPRD, DPD, the president and vice president, is a means of implementing the rule of the people who carried out directly, generally, freely, confidentially, honestly and fairly in the Unitary State of the Republic of Indonesia based on Pancasila and Constitution of the Republic of Indonesia (UUD) 1945. Within the Islamic political jurisprudence's perspective, the duties and authorities of the General Election Commission in selecting the candidate for president and vice president participants are not contrary to the principles or the Islamic teachings. They also more emphasize to consultation and transparency in justice in doing the job. Otherwise, KPU can also be equated with ah/ul halli wal aqdi institution. This institutions has the authority to decide and accommodate the aspirations of the people and institutions that have duty to determine a leader.
\end{abstract}

Keywords: Electoral commission, president, Islamic political jurisprudence.

Abstrak: Artikel ini membahas tentang kewenangan Komisi Pemilihan Umum (KPU) dalam menetapkan pasangan calon presiden dan wakil presiden menurut Undang-Undang pemilu No.42 tahun 2008 dan pandangan fikih siyâsah. Komisi Pemilihan Umum (KPU) adalah lembaga penyelengara pemilu yang berifat nasional, tetap dan mandiri. Pemilihan umum atau pemilu yang diselenggarakan oleh KPU adalah untuk memilih anggota DPR, DPRD, DPD, presiden dan wakil presiden merupakan sarana pelaksana kedaulatan rakyat yang dilaksanakan secara langsung, umum, bebas, rahasia, jujur dan adil dalam Negara kesatuan Republik Indonesia yang berdasarkan Pancasila 
dan Undang-Undang Dasar Republik Indonesia tahun 1945. Dalam perspektif fikih siyâsah, tugas dan kewenangan KPU di dalam melakukan seleksi pasangan calon presiden dan wakil presiden peserta pemilu tidak bertentangan dengan prinsip atau ajaran Islam yang mengedepankan musyawarah dan keadilan sekaligus transparansi dalam melakukan tugas, selain itu KPU bisa disamakan dengan lembaga ahlul halli wal aqdi. Dimana lembaga tersebut berarti melonggarkan dan mengikat, yang memiliki kewenangan untuk memutuskan dan dengan kata lain, lembaga ahlul halli wal aqdi adalah lembaga perwakilan yang menampung dan menyalurkan aspirasi rakyat sekaligus lembaga yang memiliki tugas untuk menyelenggarakan pemilihan khalifah (pemimpin).

Kata Kunci: Komisi pemilihan umum, presiden, fikih siyâsah.

\section{Pendahuluan}

Di dalam sistem pemerintahan modern, khususnya pada negara yang menganut sistem demokrasi seperti Indonesia, pemilihan kepala negara (presiden) diselenggrakan melalui pemilu yang diselenggarakan oleh Komisi Pemilihan Umum (KPU) dimana rakyat berhak berhak memilih dan menentukan siapa yang menjadi pemimpin tanpa adanya intervensi dari pihak lain, dengan kata lain one man in vole. Pemilihan umum merupakan salah satu dari prinsip demokrasi yang harus ada dan dijalankan dengan prinsip jujur, adil, luber dan teratur. Selain itu pemilu diselenggarakan untuk memilih presiden, wakil presiden, DPR, DPRD propinsi, DPRD kabupaten kota dan DPD.

Partai politik yang akan mengikuti proses pemilu dan berkompetisi dengan partai yang lain harus terlebih dahulu mengikuti proses kualifikasi yang diadakan oleh Menteri Hukum dan HAM setelah itu oleh Komisi Pemilihan Umum (KPU). Persyaratan-persyaratan harus dipenuhi oleh partai politik untuk menjadi peserta pemilu telah diatur dalam Undang-Undang No. 10 Tahun 2008 Tentang pemilu Anggota DPR, DPD dan DPRD pasal 8 ayat 1 dan 2 adalah sebagai berikut: ${ }^{1}$

' UU No. 10 Tahun 2008 Tentang Pemilu pasal 8.

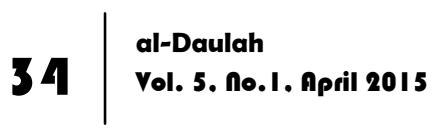


1. Partai Politik Peserta Pemilu pada Pemilu terakhir yang memenuhi ambang batas perolehan suara dari jumlah suara sah secara nasional ditetapkan sebagai Partai Politik Peserta Pemilu pada Pemilu berikutnya.

2. Partai politik yang tidak memenuhi ambang batas perolehan suara pada Pemilu sebelumnya atau partai politik baru dapat menjadi Peserta Pemilu setelah memenuhi persyaratan:

a. berstatus badan hukum sesuai dengan Undang-Undang tentang Partai politik;

b. memiliki kepengurusan di seluruh provinsi;

c. memiliki kepengurusan di $75 \%$ (tujuh puluh lima persen) jumlah kabupaten/kota di provinsi yang bersangkutan;

d. memiliki kepengurusan di 50\% (lima puluh persen) jumlah kecamatan di kabupaten/kota yang bersangkutan;

e. menyertakan sekurang-kurangnya $30 \%$ (tiga puluh persen) keterwakilan perempuan pada kepengurusan partai politik tingkat pusat;

f. memiliki anggota sekurang-kurangnya 1.000 (seribu) orang atau 1/1.000 (satu perseribu) dari jumlah Penduduk pada kepengurusan partai politik sebagaimana dimaksud pada huruf c yang dibuktikan dengan kepemilikan kartu tanda anggota;

g. mempunyai kantor tetap untuk kepengurusan pada tingkatan pusat, provinsi, dan kabupaten/kota sampai tahapan terakhir Pemilu;

h. mengajukan nama, lambang, dan tanda gambar partai politik kepada KPU; dan

i. menyerahkan nomor rekening dana Kampanye Pemilu atas nama partai politik kepada KPU.

Dalam Undang-Undang Dasar 1945 pasal 22 huruf E juga dijelaskan bahwa Pemilihan Umum dilaksanakan secara langsung, umum, bebas, rahasia, jujur dan adil setiap lima tahun sekali yang diselenggrakan untuk memilih anggota Dewan Perwakilan Rakyat (DPR), Dewan Perwakilan Daerah (DPD), presiden dan wakil 
presiden dan Dewan Perwakilan Rakyat Daerah (DPRD), dimana peserta pemilhan umum untuk memilih Dewan Perwakilan dan presiden serta wakil presiden adalah partai politik yang diselenggarakan oleh suatu komisi yang bernama Komisi Pemilihan Umum (KPU). KPU merupakan lembaga penyelenggara pemilu yang bersifat nasional, tetap dan mandiri.

Pemilihan umum yang diselenggarakan oleh KPU tersebut merupakan saran untuk mewujudkan kedaulatan rakyat guna menghasilkan pemerintahan negara yang demokratis berdasarkan Pancasila dan Undang-Undang Dasar 1945 Republik Indonesia.

Dalam Pasal 10 Undang-undang Nomor 3 Tahun 1999 tentang Pemilihan Umum dan Pasal 2 Keputusan Presiden Nomor 16 Tahun 1999 tentang Pembentukan Komisi Pemilihan Umum dan Penetapan Organisasi dan Tata Kerja Sekretariat Umum Komisi Pemilihan Umum, dijelaskan bahwa untuk melaksanakan Pemilihan Umum, KPU mempunyai tugas kewenangan sebagai berikut :

1. merencanakan dan mempersiapkan pelaksanaan Pemilihan Umum;

2. menerima, meneliti dan menetapkan Partai-partai Politik yang berhak sebagai peserta Pemilihan Umum;

3. membentuk Panitia Pemilihan Indonesia yang selanjutnya disebut PPI dan mengkoordinasikan kegiatan Pemilihan Umum mulai dari tingkat pusat sampai di Tempat Pemungutan Suara yang selanjutnya disebut TPS;

4. menetapkan jumlah kursi anggota DPR, DPRD I dan DPRD II untuk setiap daerah pemilihan;

5. menetapkan keseluruhan hasil Pemilihan Umum di semua daerah pemilihan untuk DPR, DPRD I dan DPRD II;

6. mengumpulkan dan mensistemasikan bahan-bahan serta data hasil Pemilihan Umum;

7. memimpin tahapan kegiatan Pemilihan Umum.

Dalam Pasal 2 Keputusan Presiden Nomor 16 Tahun 1999 terdapat tambahan huruf: 
"Tugas dan kewenangan lainnya yang ditetapkan dalam Undang-undang Nomor 3 Tahun 1999 tentang Pemilihan Umum."

Sedangkan dalam Pasal 11 Undang-undang Nomor 3 Tahun 1999 tersebut juga ditambahkan, bahwa selain tugas dan kewenangan KPU sebagai dimaksud dalam Pasal 10, selambatlambatnya 3 (tiga) tahun setelah Pemilihan Umum dilaksanakan, KPU mengevaluasi sistem Pemilihan Umum.

Berangkat dari latar belakang di atas, skripsi ini ditulis untuk mengetahui bagaimanakah pandangan fiqhsiyâsah terhadap wewenang KPU dalam menetapkan pasangan calon presiden dan wakil presiden menurut Undang-undang Pemilu no. 42 tahun 2008. Dalam tulisan ini penulis akan membahas mengenai kewenangan KPU dan teknis dalam meenetapkan pasangan calon presiden dan wakil presiden dengan cara sendiri atau koalisi bersama partai politik yang tidak memenuhi suara yang telah ditetapkan oleh undang-undang dan mengikuti pemilihan anggota DPR, DPRD propinsi dan DPRD kabupaten/kota.

Untuk mengetahui lebih lanjut mengenai wewenang KPU dalam menetapkan calon presiden dan wakil presiden dan perbedaan antara ahlul halli wal aqdi sebagai lembaga yang mempunyai wewenang yang sama dengan KPU dalam Islam, maka penelitian ini dilakukan secara mendalam mengenai pandangan fiqhsiyâsah terhadap wewenang KPU dalam menetapkan calon presiden dan wakil presiden di Indonesia.

\section{Kewenangan KPU dalam Menetapkan Pasangan Calon Presiden dan Wakil Presiden}

Komisi Pemilihan Umum (KPU) adalah lembaga penyelengara pemilu yang berifat nasional, tetap dan mandiri. Pemilihan umum atau pemilu yang diselenggarakan oleh KPU adalah untuk memilih anggota DPR, DPRD, DPD, presiden dan wakil presiden merupakan sarana pelaksana kedaulatan rakyat yang dilaksanakan secara langsung, umum, bebas, rahasia, jujur 
dan adil dalam Negara kesatuan Republik Indonesia yang berdasarkan Pancasila dan Undang-Undang Dasar Republik Indonesia tahun $1945 .{ }^{2}$

Dalam Undang-undang Nomor 22 Tahun 2007 Tentang Penyelenggara Pemilu diatur mengenai penyelenggara Pemilihan Umum yang dilaksanakan oleh suatu Komisi Pemilihan Umum (KPU) yang bersifat nasional, tetap, dan mandiri. Sifat nasional mencerminkan bahwa wilayah kerja dan tanggung jawab KPU sebagai penyelenggara Pemilihan Umum mencakup seluruh wilayah Negara Kesatuan Republik Indonesia. Sifat tetap menunjukkan KPU sebagai lembaga yang menjalankan tugas secara berkesinambungan meskipun dibatasi oleh masa jabatan tertentu. Sifat mandiri menegaskan KPU dalam menyelenggarakan Pemilihan Umum bebas dari pengaruh pihak mana pun.

Perubahan penting dalam undang-undang Nomor 22 Tahun 2007 Tentang Penyelenggara Pemilu, meliputi pengaturan mengenai lembaga penyelenggara Pemilihan Umum Anggota Dewan Perwakilan Rakyat, Dewan Perwakilan Daerah, dan Dewan Perwakilan Rakyat Daerah; Pemilihan Umum Presiden dan Wakil Presiden; serta Pemilihan Umum Kepala Daerah dan Wakil Kepala Daerah yang sebelumnya diatur dalam beberapa peraturan perundang-undangan kemudian disempurnakan dalam 1 (satu) undang-undang secara lebih komprehensif.

Dalam undang-undang Nomor 22 Tahun 2007 Tentang Penyelenggara Pemilu diatur mengenai KPU, KPU Provinsi, dan KPU Kabupaten/Kota sebagai lembaga penyelenggara pemilihan umum yang permanen dan Bawaslu sebagai lembaga pengawas Pemilu. KPU dalam menjalankan tugasnya bertanggung jawab sesuai dengan peraturan perundang-undangan serta dalam hal penyelenggaraan seluruh tahapan pemilihan umum dan tugas lainnya. KPU memberikan laporan Presiden kepada Dewan Perwakilan Rakyat.

${ }^{2}$ UU No. 10 Tahun 2008 Pasal I. 
Undang-undang Nomor 22 Tahun 2007 Tentang Penyelenggara Pemilu juga mengatur kedudukan panitia pemilihan yang meliputi PPK, PPS, KPPS dan PPLN serta KPPSLN yang merupakan penyelenggara Pemilihan Umum yang bersifat ad hoc. Panitia tersebut mempunyai peranan penting dalam pelaksanaan semua tahapan penyelenggaraan Pemilihan Umum dalam rangka mengawal terwujudnya Pemilihan Umum secara langsung, umum, bebas, rahasia, jujur, dan adil.

Dalam rangka mewujudkan KPU dan Bawaslu yang memiliki integritas dan kredibilitas sebagai Penyelenggara Pemilu, disusun dan ditetapkan Kode Etik Penyelenggara Pemilu. Agar Kode Etik Penyelenggara Pemilu dapat diterapkan dalam penyelenggaraan Pemilihan Umum, dibentuk Dewan Kehormatan KPU, KPU Provinsi, dan Bawaslu.

Menurut Undang-undang Nomor 22 Tahun 2007 Tentang Penyelenggara Pemilu, komposisi keanggotaan KPU harus memperhatikan keterwakilan perempuan sekurang-kurangnya 30\% (tiga puluh persen). Masa keanggotaan KPU 5 (lima) tahun terhitung sejak pengucapan sumpah/janji.

"Komposisi keanggotaan KPU, KPU Provinsi, dan KPU

Kabupaten/Kota memperhatikan keterwakilan perempuan sekurang-kurangnya 30\% (tiga puluh perseratus)." 3

Penyelenggara Pemilu berpedoman kepada asas : mandiri, jujur, adil, kepastian hukum, tertib penyelenggara Pemilu, kepentingan umum, keterbukaan, proporsionalitas, profesionalitas, akuntabilitas, efisiensi dan efektivitas.

“Penyelenggara Pemilu berpedoman kepada asas:
a. mandiri;
b. jujur;
c. adil;
d. kepastian hukum;
e. tertib penyelenggara Pemilu; 


\section{f. kepentingan umum; \\ g. keterbukaan; \\ h. proporsionalitas; \\ i. profesionalitas; \\ j. akuntabilitas; \\ k. efisiensi; dan \\ 1. efektivitas."}

Secara ringkas, KPU yang ada sekarang merupakan KPU keempat yang dibentuk sejak era Reformasi 1998. KPU pertama (1999-2001) dibentuk dengan Keppres No 16 Tahun 1999, beranggotakan 53 orang anggota, dari unsur pemerintah dan Partai Politik. KPU pertama dilantik Presiden BJ Habibie. KPU kedua (2001-2007) dibentuk dengan Keppres No 10 Tahun 2001, beranggotakan 11 orang, dari unsur akademis dan LSM. KPU kedua dilantik oleh Presiden Abdurrahman Wahid (Gus Dur) pada tanggal 11 April 2001.

KPU ketiga (2007-2012) dibentuk berdasarkan Keppres No 101/P/2007 yang berisikan tujuh orang anggota yang berasal dari anggota KPU Provinsi, akademisi, peneliti dan birokrat dilantik tanggal 23 Oktober 2007 minus Syamsulbahri yang urung dilantik Presiden karena masalah hukum.

Untuk menghadapi pelaksanaan Pemilihan Umum 2009, image KPU harus diubah sehingga KPU dapat berfungsi secara efektif dan mampu memfasilitasi pelaksanaan Pemilu yang jujur dan adil. Terlaksananya Pemilu yang jujur dan adil tersebut merupakan faktor penting bagi terpilihnya wakil rakyat yang lebih berkualitas, dan mampu menyuarakan aspirasi rakyat. Sebagai anggota KPU, integritas moral sebagai pelaksana pemilu sangat penting, selain menjadi motor penggerak KPU juga membuat KPU lebih kredibel di mata masyarakat karena didukung oleh personal yang jujur dan adil.

${ }^{4}$ Ibid., Pasal 2. 
Tepat tiga tahun setelah berakhirnya penyelenggaraan Pemilu 2004, muncul pemikiran di kalangan pemerintah dan DPR untuk meningkatkan kualitas pemilihan umum, salah satunya kualitas penyelenggara Pemilu. Sebagai penyelenggara pemilu, KPU dituntut independen dan non-partisan.

Untuk itu atas usul insiatif DPR-RI menyusun dan bersama pemerintah mensyahkan Undang-undang Nomor 22 Tahun 2007 Tentang Penyelenggara Pemilu. Sebelumnya keberadaan penyelenggara Pemilu terdapat dalam Pasal 22-E Undang-undang Dasar Tahun 1945 dan Undang-undang Nomor 12 Tahun 2003 Tentang Pemilu DPR, DPD dan DPRD, Undang-undang Nomor 23 Tahun 2003 Tentang Pemilu Presiden dan Wakil Presiden. ${ }^{5}$

\section{Syarat untuk Menjadi Anggota KPU}

Syarat untuk menjadi calon anggota KPU pusat, KPU Provinsi, atau KPU Kabupaten/Kota adalah:

1. Warga negara Indonesia;

2. Pada saat pendaftaran berusia paling rendah 35 (tiga puluh lima) tahun untuk calon anggota KPU dan berusia paling rendah 30 (tiga puluh) tahun untuk calon anggota KPU Provinsi atau KPU Kabupaten/Kota;

3. Setia kepada Pancasila sebagai dasar negara, Undang-Undang Dasar Negara Republik Indonesia Tahun 1945, dan cita-cita Proklamasi 17 Agustus 1945;

4. Mempunyai integritas, pribadi yang kuat, jujur, dan adil;

5. Memiliki pengetahuan dan keahlian yang berkaitan dengan penyelenggaraan Pemilu;

6. Berpendidikan paling rendah S-1 untuk calon anggota KPU, KPU Provinsi, dan paling rendah SLTA atau sederajat untuk calon anggota KPU Kabupaten/Kota;

5 Ahmad Fathoni, "KomisiPemilihanUmum", http://id.wikipedia.org/wiki/Komisi_ Pemilihan_Umum diakses pada selas 24 des 2013 pkl 14.20

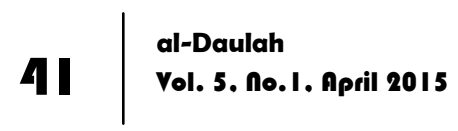


7. Berdomisili di wilayah Republik Indonesia bagi anggota KPU dan di wilayah provinsi yang bersangkutan bagi anggota KPU Provinsi, serta di wilayah kabupaten/kota yang bersangkutan bagi anggota KPU Kabupaten/Kota yang dibuktikan dengan kartu tanda penduduk;

8. Mampu secara jasmani dan rohani;

9. Mengundurkan diri dari keanggotaan partai politik, jabatan politik, jabatan di pemerintahan, dan Badan Usaha Milik Negara/Badan Usaha Milik Daerah pada saat mendaftar sebagai calon;

10. Tidak pernah dipidana penjara berdasarkan putusan pengadilan yang telah memperoleh kekuatan hukum tetap karena melakukan tindak pidana yang diancam dengan pidana penjara 5 (lima) tahun atau lebih;

11. Bersedia bekerja penuh waktu;

12. Bersedia tidak menduduki jabatan politik, jabatan di pemerintahan dan Badan Usaha Milik Negara/Badan Usaha Milik Daerah selama masa keanggotaan apabila terpilih; dan

13. Tidak berada dalam satu ikatan perkawinan dengan sesama Penyelenggara Pemilu. ${ }^{6}$

Pengangkatan atau pemilihan KPU melalui beberapa tahap di antaranya adalah:

1. Presiden membentuk tim seleksi calon anggota KPU.

2. Tim seleksi membantu presiden untuk menetapkan calon anggota KPU yang akan diajukan kepada dewan perwakilan rakyat dengan tahapan sebagaimana diatur dalam UU.

3. Setelah melakukan proses seleksi yang diselenggarakan oleh tim seleksi. Maka panitia menyerahkan 21 nama ke presiden untuk ditetapkan.

4. Setelah ditetapkan 21 nama tersebut oleh presiden, nama-nama tersebut diserahkan kepada dewan perwakilan rakyat untuk dipilih.

${ }^{6}$ Undang-Undang Republik Indonesia Nomor 15 Tahun 20 I I bagian ke empat pasal I I .

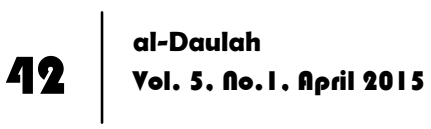


5. Proses pemilihan angota KPU di dewan rakyat dilakukan paling lambat dalam waktu 20 hari.

6. Dewan Perwakilan Rakyat menetapkan tujuh peringkat teratas, setelah itu DPR menyampaikan anggota KPU terpilih kepada presiden.

7. Anggota KPU yang sudah terpilih tersebut setelah diserahkan kepada presiden, presden menetapkan dengan keputusan presiden paling lambat 5 (lima) hari terhitung sejak berkas nama-nama anggota KPU terpilih diserahkan oleh DPR. ${ }^{7}$

\section{Tugas dan Kedudukan KPU Pusat dalam Menentukan Calon Presiden dan Wakil Pesiden}

Menurut Undang-Undang Republik Indonesia Nomor 15 Tahun 2011 paragraf I pasal 8 butir ke 2, Tugas dan wewenang KPU Pusat dalam penyelenggaraan Pemilu Presiden dan Wakil Presiden meliputi: ${ }^{8}$

a. Merencanakan program dan anggaran serta menetapkan jadwal;

b. Menyusun dan menetapkan tata kerja KPU, KPU Provinsi, KPU Kabupaten/Kota, PPK, PPS, KPPS, PPLN, dan KPPSLN;

c. Menyusun dan menetapkan pedoman teknis untuk setiap tahapan Pemilu setelah terlebih dahulu berkonsultasi dengan DPR dan Pemerintah;

d. Mengoordinasikan, menyelenggarakan, dan mengendalikan semua tahapan;

e. Menerima daftar pemilih dari KPU Provinsi;

f. Memutakhirkan data pemilih berdasarkan data kependudukan yang disiapkan dan diserahkan oleh Pemerintah dengan memperhatikan data Pemilu dan/atau pemilihan gubernur, bupati, dan walikota terakhir dan menetapkannya sebagai daftar pemilih; 
g. Menetapkan pasangan calon presiden dan calon wakil presiden yang telah memenuhi persyaratan;

h. Menetapkan dan mengumumkan hasil rekapitulasi penghitungan suara berdasarkan hasil rekapitulasi penghitungan suara di KPU Provinsi dengan membuat berita acara penghitungan suara dan sertifikat hasil penghitungan suara;

i. Membuat berita acara penghitungan suara serta membuat sertifikat penghitungan suara dan wajib menyerahkannya kepada saksi peserta Pemilu dan Bawaslu;

j. Menerbitkan keputusan KPU untuk mengesahkan hasil Pemilu dan mengumumkannya;

k. Mengumumkan pasangan calon presiden dan wakil presiden terpilih dan membuat berita acaranya;

1. Menetapkan standar serta kebutuhan pengadaan dan pendistribusian perlengkapan;

$\mathrm{m}$. Menindaklanjuti dengan segera rekomendasi Bawaslu atas temuan dan laporan adanya dugaan pelanggaran Pemilu;

n. Mengenakan sanksi administratif dan/atau menonaktifkan sementara anggota KPU Provinsi, anggota PPLN, anggota KPPSLN, Sekretaris Jenderal KPU, dan pegawai Sekretariat Jenderal KPU yang terbukti melakukan tindakan yang mengakibatkan terganggunya tahapan penyelenggaraan Pemilu berdasarkan rekomendasi Bawaslu dan/atau ketentuan peraturan perundang-undangan;

o. Melaksanakan sosialisasi penyelenggaraan Pemilu dan/atau yang berkaitan dengan tugas dan wewenang KPU kepada masyarakat;

p. Menetapkan kantor akuntan publik untuk mengaudit dana kampanye dan mengumumkan laporan sumbangan dana kampanye;

q. Melakukan evaluasi dan membuat laporan setiap tahapan penyelenggaraan Pemilu; dan 
r. Melaksanakan tugas dan wewenang lain sesuai ketentuan peraturan perundang-undangan.

Prosedur dan Teknik KPU dalam Menentukan Calon Presiden dan Wakil Presiden Menurut Undang-Undang Nomor 42 Tahun 2008

Berdasarkan Udang-Undang No.48 Tahun 2008, Pemilihan Umum Presiden dan Wakil Presiden, selanjutnya disebut Pemilu Presiden dan Wakil Presiden, adalah pemilihan umum untuk memilih Presiden dan Wakil Presiden dalam Negara Kesatuan Republik Indonesia berdasarkan Pancasila dan Undang-Undang Dasar Negara Republik Indonesia Tahun 1945 yang pelaksaannya dilakukan oleh KPU dan di bawah pengawasan Bawaslu. ${ }^{9}$

Pasangan Calon Presiden dan Wakil Presiden, selanjutnya disebut Pasangan Calon, adalah pasangan calon peserta Pemilu Presiden dan Wakil Presiden yang diusulkan oleh Partai Politik atau Gabungan Partai Politik yang telah memenuhi persyaratan. Ada beberapa syarat menjadi calon presiden dan wakil presiden antara lain:

1. Bertakwa kepada Tuhan Yang Maha Esa;

2. Warga Negara Indonesia sejak kelahirannya dan tidak pernah menerima kewarganegaraan lain karena kehendaknya sendiri;

3. Tidak pernah mengkhianati negara, serta tidak pernah melakukan tindak pidana korupsi dan tindak pidana berat lainnya;

4. Mampu secara rohani dan jasmani untuk melaksanakan tugas dan kewajiban sebagai Presiden dan Wakil Presiden;

5. Bertempat tinggal di wilayah Negara Kesatuan Republik Indonesia;

${ }_{9}$ Undang-Undang Nomor 42 Tahun 2008 Pasal I.

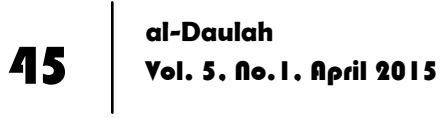


6. Telah melaporkan kekayaannya kepada instansi yang berwenang memeriksa laporan kekayaan penyelenggara negara;

7. Tidak sedang memiliki tanggungan utang secara perseorangan dan/atau secara badan hukum yang menjadi tanggung jawabnya yang merugikan keuangan negara;

8. Tidak sedang dinyatakan pailit berdasarkan putusan pengadilan;

9. Tidak pernah melakukan perbuatan tercela;

10. Terdaftar sebagai Pemilih;

11. Memiliki Nomor Pokok Wajib Pajak (NPWP) dan telah melaksanakan kewajiban membayar pajak selama 5 (lima) tahun terakhir yang dibuktikan dengan Surat Pemberitahuan Tahunan Pajak Penghasilan Wajib Pajak Orang Pribadi;

12. Belum pernah menjabat sebagai Presiden atau Wakil Presiden selama 2 (dua) kali masa jabatan dalam jabatan yang sama;

13. Setia kepada Pancasila sebagai dasar negara, Undang-Undang Dasar Negara Republik Indonesia Tahun 1945, dan cita-cita Proklamasi 17 Agustus 1945;

14. Tidak pernah dijatuhi pidana penjara berdasarkan putusan pengadilan yang telah mempunyai kekuatan hukum tetap karena melakukan tindak pidana yang diancam dengan pidana penjara 5 (lima) tahun atau lebih;

15. Berusia sekurang-kurangnya 35 (tiga puluh lima) tahun;

16. Berpendidikan paling rendah tamat Sekolah Menengah Atas (SMA), Madrasah Aliyah (MA), Sekolah Menengah Kejuruan (SMK), Madrasah Aliyah Kejuruan (MAK), atau bentuk lain yang sederajat;

17. Bukan bekas anggota organisasi terlarang Partai Komunis Indonesia, termasuk organisasi massanya, atau bukan orang yang terlibat langsung dalam G.30.S/PKI; dan 
18. Memiliki visi, misi, dan program dalam melaksanakan pemerintahan negara Republik Indonesia. ${ }^{10}$

Pemilu Presiden dan Wakil Presiden dilaksanakan secara efektif dan efisien berdasarkan asas langsung, umum, bebas, rahasia, jujur, dan adil. Pemilu Presiden dan Wakil Presiden ini dilaksanakan setiap 5 (lima) tahun sekali. Pemilu Presiden dan Wakil Presiden dilaksanakan di seluruh wilayah Negara Kesatuan Republik Indonesia sebagai satu kesatuan daerah pemilihan. Pemungutan suara dilaksanakan secara serentak pada hari libur atau hari yang diliburkan. Hari, tanggal, dan waktu pemungutan suara Pemilu Presiden dan Wakil Presiden ditetapkan dengan keputusan KPU. Pemilu Presiden dan Wakil Presiden dilaksanakan setelah pelaksanaan pemilihan umum anggota DPR, DPD, dan DPRD. Secara singkat ada beberapa tahapan penyelenggaraan Pemilu Presiden dan Wakil Presiden yang meliputi:

1. Penyusunan daftar Pemilih;

2. Pendaftaran bakal Pasangan Calon;

3. Penetapan Pasangan Calon;

4. Masa Kampanye;

5. Masa tenang;

6. Pemungutan dan penghitungan suara;

7. Penetapan hasil Pemilu Presiden dan Wakil Presiden; dan

8. Pengucapan sumpah/janji Presiden dan Wakil Presiden.

9. Penetapan Pasangan Calon terpilih paling lambat 14 (empat belas) hari sebelum berakhirnya masa jabatan Presiden dan Wakil Presiden. ${ }^{11}$

Setelah tahapan-tahapan tersebut dilalui oleh para calon presiden dan wakil presiden di atas, masih ada beberapa mekanisme yang harus mereka lalui. Calon Presiden dan calon Wakil Presiden diusulkan dalam 1 (satu) pasangan oleh Partai Politik atau Gabungan Partai Politik. Pasangan Calon diusulkan

\footnotetext{
${ }^{10}$ Ibid., Pasal 5.

1 Ibid., Pasal 3.
} 
oleh Partai Politik atau Gabungan Partai Politik peserta pemilu yang memenuhi persyaratan perolehan kursi paling sedikit $20 \%$ (dua puluh persen) dari jumlah kursi DPR atau memperoleh 25\% (dua puluh lima persen) dari suara sah nasional dalam Pemilu anggota DPR, sebelum pelaksanaan Pemilu Presiden dan Wakil Presiden. ${ }^{12}$

Penentuan calon Presiden dan/atau calon Wakil Presiden dilakukan secara demokratis dan terbuka sesuai dengan mekanisme internal Partai Politik bersangkutan. Selain berdiri sendiri, Partai Politik yang kurang mendapat suara pada pemilu sebelumnya dapat melakukan kesepakatan dengan Partai Politik lain untuk melakukan penggabungan (kualifikasi) dalam mengusulkan pasangan calon dan Partai Politik atau gabungan Partai Politik sebagaimana dimaksud pada ayat (2) hanya dapat mencalonkan 1 (satu) pasangan Calon sesuai dengan mekanisme internal Partai Politik dan/atau secara musyawarah jika terdiri dari gabungan Partai Politik yang tetap harus dilakukan secara demokratis dan terbuka dan Calon Presiden dan/atau calon Wakil Presiden yang telah diusulkan dalam satu pasangan oleh Partai Politik atau Gabungan Partai Politik sebagaimana dimaksud pada ayat (3) tidak boleh dicalonkan lagi oleh Partai Politik atau Gabungan Partai Politik lainnya. ${ }^{13}$ Setelah itu baru dilakukannya pendaftaran bakal pasangan calon oleh partai politik yang harus ditandatangani oleh ketua umum atau sebutan lain dan sekretaris jenderal atau sebutan lain sesuai dengan ketentuan peraturan perundang-undangan.

Adapun pendaftaran bakal pasangan calon yang diusung oleh satu partai politik sebagaimana dimaksud dalam Pasal 13 harus dilengkapi dengan persyaratan sebagai berikut:

1. Kartu tanda penduduk dan akta kelahiran Warga Negara Indonesia;

13 Ibid, Pasal 10. 
2. Surat keterangan catatan kepolisian dari Markas Besar Kepolisian Negara Republik Indonesia;

3. Surat keterangan kesehatan dari rumah sakit Pemerintah yang ditunjuk oleh KPU;

4. Surat tanda terima atau bukti penyampaian laporan harta kekayaan pribadi kepada Komisi Pemberantasan Korupsi (KPK);

5. Surat keterangan tidak sedang dalam keadaan pailit dan/atau tidak memiliki tanggungan utang yang dikeluarkan oleh pengadilan negeri;

6. Fotokopi NPWP dan tanda bukti pengiriman atau penerimaan Surat Pemberitahuan Tahunan Pajak Penghasilan Wajib Pajak Orang Pribadi selama 5 (lima) tahun terakhir;

7. Daftar riwayat hidup, profil singkat, dan rekam jejak setiap bakal calon;

8. Surat pernyataan belum pernah menjabat sebagai Presiden atau Wakil Presiden selama 2 (dua) kali masa jabatan dalam jabatan yang sama;

9. Surat pernyataan setia kepada Pancasila sebagai dasar negara, Undang-Undang Dasar Negara Republik Indonesia Tahun 1945, dan cita-cita Proklamasi 17 Agustus 1945 sebagaimana yang dimaksud dalam Pembukaan UndangUndang Dasar Negara Republik Indonesia Tahun 1945;

10. Surat keterangan dari pengadilan negeri yang menyatakan bahwa setiap bakal calon tidak pernah dijatuhi pidana penjara berdasarkan putusan pengadilan yang telah mempunyai kekuatan hukum tetap karena melakukan tindak pidana yang diancam dengan pidana penjara 5 (lima) tahun atau lebih;

11. Bukti kelulusan berupa fotokopi ijazah, STTB, syahadah, sertifikat, atau surat keterangan lain yang dilegalisasi oleh satuan pendidikan atau program pendidikan menengah; 
12. Surat keterangan tidak terlibat organisasi terlarang dan G.30.S/PKI dari kepolisian; dan

13. Surat pernyataan bermeterai cukup tentang kesediaan yang bersangkutan diusulkan sebagai bakal calon Presiden dan bakal calon Wakil Presiden secara berpasangan.

Semua persyaratan di atas harus disertakan oleh pasangan calon presiden dan wakil calon presiden selama masa pendaftran berlangsung yakni paling lama 7 (tujuh) hari terhitung sejak penetapan secara nasional hasil Pemilu anggota DPR. ${ }^{14}$

Sedangkan bagi para calon presiden dan calon wakil presiden yang berasal dari kualisi partai juga harus menyerahkan beberapa berkas saat pendaftaran, antara lain:

1. surat pencalonan yang ditandatangani oleh ketua umum atau sebutan lain dan sekretaris jenderal atau sebutan lain Partai Politik atau ketua umum atau sebutan lain dan sekretaris jenderal atau sebutan lain Partai Politik yang bergabung sesuai dengan ketentuan peraturan perundangundangan;

2. kesepakatan tertulis antar-Partai Politik sebagaimana dimaksud dalam Pasal 11 ayat (1) huruf a;

3. surat pernyataan tidak akan menarik pencalonan atas pasangan yang dicalonkan yang ditandatangani oleh pimpinan Partai Politik atau para pimpinan Partai Politik yang bergabung;

4. kesepakatan tertulis antara Partai Politik atau Gabungan Partai Politik dengan bakal Pasangan Calon sebagaimana dimaksud dalam Pasal 11 ayat (1) huruf b;

5. naskah visi, misi, dan program dari bakal Pasangan Calon;

6. surat pernyataan dari bakal Pasangan Calon tidak akan mengundurkan diri sebagai Pasangan Calon; dan kelengkapan persyaratan bakal calon Presiden dan bakal

${ }^{14}$ Ibid., Pasal 14. 
calon Wakil Presiden sebagaimana dimaksud dalam Pasal 14 ayat (1). ${ }^{15}$

Selanjutnya yang merupakan tahapan terakhir dari tata cara pemilihan calon presiden dan wakil presiden menurut UndangUndang nomor 42 Tahun 2008 adalah verifikasi bakal asangan calon. Dalam hal ini KPU melakukan verifikasi terhadap kelengkapan dan kebenaran dokumen persyaratan administratif bakal Pasangan Calon paling lama 4 (empat) hari sejak diterimanya surat pencalonan kemudian KPU memberitahukan secara tertulis hasil verifikasi terhadap kelengkapan dan kebenaran dokumen persyaratan administratif sebagaimana dimaksud pada ayat (1) kepada pimpinan Partai Politik atau pimpinan Partai Politik yang bergabung dan Pasangan Calon pada hari kelima sejak diterimanya surat pencalonan. ${ }^{16}$

Dalam hal persyaratan administratif bakal pasangan calon sebagaimana dimaksud dalam Pasal 14 dan Pasal 15 belum lengkap, KPU memberikan kesempatan kepada pimpinan partai politik atau para pimpinan Partai Politik yang bergabung dan/atau bakal pasangan calon untuk memperbaiki dan/atau melengkapi dalam waktu paling lama 3 (tiga) hari sejak diterimanya surat pemberitahuan hasil verifikasi dari KPU sebagaimana dimaksud dalam Pasal 16 ayat (2). Selanjutnya, pimpinan partai politik atau para pimpinan Partai Politik yang bergabung dan/atau bakal pasangan calon menyerahkan hasil perbaikan dan/atau kelengkapan persyaratan administratif bakal pasangan calon kepada KPU paling lambat pada hari keempat sejak diterimanya surat pemberitahuan hasil verifikasi sebagaimana dimaksud pada ayat (1). Setelah tahapan tersebut, KPU memberitahukan secara tertulis hasil verifikasi ulang kepada pimpinan partai politik atau para pimpinan partai politik yang bergabung dan/atau bakal Pasangan Calon paling lambat pada hari ketiga sejak diterimanya

15 Ibid., Pasal 15.

16 Ibid.,Pasal 16. 
hasil perbaikan dan/atau kelengkapan administratif bakal pasangan calon sebagaimana dimaksud pada ayat (2). ${ }^{17}$

Jika dalam hal bakal pasangan calon yang diusulkan tidak memenuhi persyaratan sebagaimana dimaksud dalam Pasal 14 dan Pasal 15, KPU meminta kepada Partai Politik dan/atau gabungan partai politik yang bersangkutan untuk mengusulkan bakal Pasangan Calon yang baru sebagai pengganti. Pengusulan bakal Pasangan Calon sebagaimana dimaksud pada ayat (1) dilakukan paling lama 7 (tujuh) hari sejak surat permintaan dari KPU diterima oleh Partai Politik dan/atau Gabungan Partai Politik dan kemudian KPU melakukan verifikasi terhadap kelengkapan dan kebenaran dokumen persyaratan administratif bakal Pasangan Calon sebagaimana dimaksud pada ayat (2) paling lama 4 (empat) hari setelah diterimanya surat pengusulan bakal Pasangan Calon baru, kemudian KPU memberitahukan secara tertulis hasil verifikasi terhadap kelengkapan dan kebenaran dokumen persyaratan administratif sebagaimana dimaksud pada ayat (3) kepada pimpinan Partai Politik dan/atau pimpinan Partai Politik yang bergabung dan bakal Pasangan Calon paling lama pada hari kelima sejak diterimanya surat pengusulan bakal Pasangan Calon yang baru. ${ }^{18}$

Dalam hal persyaratan administratif bakal Pasangan Calon sebagaimana dimaksud dalam Pasal 18 tidak lengkap dan/atau tidak benar, Partai Politik dan/atau Gabungan Partai Politik yang bersangkutan tidak dapat lagi mengusulkan bakal Pasangan Calon. Dan jika Dalam hal salah satu calon dari bakal Pasangan Calon atau kedua calon dari bakal Pasangan Calon berhalangan tetap sampai dengan 7 (tujuh) hari sebelum bakal Pasangan Calon ditetapkan sebagai calon Presiden dan Wakil Presiden, Partai Politik atau Gabungan Partai Politik yang bakal calon atau bakal Pasangan Calonnya berhalangan tetap, diberi kesempatan untuk mengusulkan bakal Pasangan Calon pengganti dan selanjutnya

\footnotetext{
${ }^{17}$ Ibid.,Pasal 17.

18 Ibid, Pasal 18.
} 
dengan tahapan yang sama seperti yang telah penulis uraikan sebelumnya sampai akhirnya ditetapkan pasangan calon presiden dan wakil presiden yang siap dipilih dalam pemilu presiden dan wakil presiden. ${ }^{19}$

Tahapan yang paling akhir yang dilakukan KPU adalah menetapkan dan mengumumkan pasangan calon yang lolos verifikasi. KPU menetapkan dalam sidang pleno KPU tertutup dan mengumumkan nama-nama pasangan calon yang telah memenuhi syarat sebagai peserta Pemilu Presiden dan Wakil Presiden, 1 (satu) hari setelah selesai verifikasi. Kemudian dilanjutkan dengan penetapan nomor urut pasangan calon sebagaimana dimaksud pada ayat (1) dilakukan secara undi dalam sidang pleno KPU terbuka dan dihadiri oleh seluruh pasangan calon,1 (satu) hari setelah penetapan dan pengumuman sebagaimana dimaksud pada ayat (1). Selanjutnya, KPU akan mengumumkan secara luas nama-nama dan nomor urut Pasangan Calon setelah sidang pleno KPU sebagaimana dimaksud pada ayat (2). Dan Partai Politik atau Gabungan Partai Politik dilarang menarik calonnya dan/atau Pasangan Calon yang telah ditetapkan oleh KPU dan Salah seorang dari Pasangan Calon atau Pasangan Calon dilarang mengundurkan diri terhitung sejak ditetapkan sebagai Pasangan Calon oleh KPU. Dalam hal ini Partai Politik atau Gabungan Partai Politik yang menarik Pasangan Calon atau salah seorang dari Pasangan Calon, Partai Politik atau Gabungan Partai Politik yang mencalonkan tidak dapat mengusulkan calon pengganti. ${ }^{20}$

\section{Pandangan Fikih Siyâsah terhadap Kewenangan KPU dalam Pelaksanaan Pemilu di Indonesia}

Jika ada yang berpendapat bahwa pemilihan umum adalah bagian dari system demokrasi, dan system demokrasi tidak boleh

\footnotetext{
19 Ibid.,Pasal 19.

20 lbid., Pasal 21.
} 
kita ambil karena tidak Islami, maka dapat dikatakan bahwa system tersebut adalah sistem Jahili, tetapi apakah kita dilarang mengambil salah satu bagian dari system jahili tersebut yang sekiranya tidak bertentangan dengan ajaran Islam?

Jawabannya adalah boleh, bahkan bisa jadi wajib untuk mengambil bagian yang benar serta bermanfaat sesuai dengan syariat dari sekian banyak bagian yang telah menjadi undangundang yang secara keseluruhannya disebut sistem Jahili, berdasarkan dua alasan berikut:21

Pertama, cukup populer dikalangan para pakar dan ahli sejarah Islam bahwa dalam undang-undang bangsa Arab Jahiliyah ada salah satu undang-undang "Al jiwar" (pemberian suaka politik) yaitu; apabila seseorang mengumumkan secara terangterangan bahwa dia memberikan jaminan perlindungan kepada individu tertentu, maka dengan cara seperti ini individu yang dilindungi telah berada dibawah perlindungannya, dan jika ada orang lain yang melakukan suatu tindakan permusuhan atau penganiayaan kepadanyaberarti dia melakukan permusuhan terhadap yang memberikan perlindungan tadi.

Undang-undang ini pernah di ambil Nabi dan para sahabatnya, beliau tidak keberatan berada dibawah jaminan perlindungan pamannnya Abu Thalib, begitupun ketika berangkat ke Thaif dan pulang kembali memasuki kota Makkah dibawah jaminan perlindungan Al Muth'im Bin 'Ady.

Kedua, Nabi saw pernah bersabda; (Aku pernah menghadiri sebuah pertemuan untuk mengadakan perjanjian, sebelum diangkat menjadi Nabi di rumah abdullah Bin jad'an, pertemuan tersebut bagiku seakan-akan memiliki untah merah (sebagai

${ }^{21}$ Abdul Karim Zaidan, dkk. Pemilu dan Parpol dalam Perspektif Syariah, (Bandung: Syaamil Cipta Media, 2003), I4- 15. 
ungkapan kebanggaaan beliau), para tokoh Quraisy berkumpul di sana mereka saling berjanji untuk membela pihak-pihak yang dizalimi di kota Makkah. "Seandainya aku (Nabi Muhammad saw) diundang kembali untuk mengahdiri pertemuan seperti itu (setelah menjadi Nabi) akan aku penuhi undangan tersebut".

Abdul Karim Zaidan, dkk telah menjelaskan dalam bukunya bahwa tidak berarti seluruh sistem demokrasi yang berlaku dalam sebuah pemerintahan harus kita ambil, tetapi ada bagian dari sistem ini yang kita tolak, misalnya: pemberian otoritas penuh bagi wakil-wakil rakyat untuk membuat undang-undang, karena hal ini dilarang dalam Islam baik secara individu maupun secara kolektif bagi siapapun tanpa terkecuali karena pembuatan undang-undang hanyalah hak mutlak bagi Allah, begitupun perubahan substansinya. ${ }^{22}$

Yang diperbolehkan adalah berijtihad, yaitu sebuah upaya untuk mengungkap dan memperjelas hukum Allah bukan membuat hukum baru, dan ijtihad itu diperbolehkan secara syar'i berdasarkan sabda Rasulullah saw: Jika seorang hakim / mujtahid berijtihad dan ternyata ijtihadnya keliru maka dia hanya mendapat satu pahala, dan jika ijtihadnya benar maka ia mendapat dua pahala. (H.R. Bukhari dan Muslim). ${ }^{23}$

Seandainya ijtihad itu dilarang maka tidak akan disediakan pahala bagi yang keliru dalam ijtihadnya. Ruang lingkup ijtihad adalah dalam perkara-perkara yang tidak ada dalam Al-Quran maupun Hadist. Maka disinilah diperlukan ijtihad, sebagaimana dilakukan oleh para ulama salaf dan dalam masalah ijtihad tidak boleh saling mencela. Bahkan para mujtahid hanya mengunkap dan memperjelas hukum Allah yang masih bersifat global, bukan

\footnotetext{
22 Ibid., 24.

23 lbid.
} 
membuat hukum yang baru. Jika mereka melakukannya tidak procedural dan tidak mengikuti ketentuan-ketentuan yang berlaku maka ijtihadnya sesuai dengan prosedur dan ketentuan-ketentuan yang telah disepakati para ulama, maka ijtihadnya wajib diterima. ${ }^{24}$

Apabila pemilihan umum dan keterlibatan kita didalamnya termasuk permasalahan ijtihad, maka dapat disimpulkan bahwa hasil ijtihad dalam masalah ini termasuk kategori ijtihad yang sangat jelas sisi kebenarannya, dan ijtihad yang lemah dan marjuh, dan kita tidak boleh mempertahankan pendapat yan lemah dan marjuh, karena pendapat yang lemah tersebut akan menghalangi pendapat yang mengandung maslahat besar bagi umat, dan yang akan memudahkan jalan meuju penegakan syariat Islam. ${ }^{25}$

Pemilihan umum termasuk salah satu permasalahan atau kasus yang terjadi di zaman sekarang di berbagai Negara. Secara ringkas, pemilu bias dipahami secara sederhana bahwa pemilu adalah dikembalikannya hak pemilih kepada umat atau rakyat dalam pemilihan para wakilnya yang akan mewakili mereka untuk berbicara atas nama rakyat, menuntut hak-haknya dan membelanya dari hal-hal yang merugikan mereka. ${ }^{26}$

Diantaranya dapat kita temukan dalam kitab-kitab fiqh klasik, para fuqofa kita pernah mengatakan: "Barang siapa yang mendapatkan persetujuan dari kaum muslimin untuk menjadi khalifah atau pemimpin maka ia akan diangkat menjadi imam atau pemimpin kaum muslimin." Tentunya, persetujuan umat terhadap seseorang akan terjadi setelah melalui proses pemilihan dan tidak mungkin dapat diketahui hanya melalui getaran hati

\footnotetext{
${ }^{24}$ Ibid., 25.

25 lbid.

${ }^{26}$ Ibid., 3.
} 
mereka, tetapi harus dibuktikan melalui pemilihan, maka perihal dkembalikannya pemilihan ini kepada umat merupakan permasalahan yang bisa dipahami dan diakui. ${ }^{27}$

Pemilu di dalam sistem demokratik, terikat dengan prinsip dan sistem demokrasi-sekuler. Pemilu dalam sistem demokrasi ditujukan untuk memilih wakil rakyat yang memiliki beberapa fungsi, salah satunya adalah fungsi legislasi dan kontrol. Hal ini dijelaskan di dalam UU No.12 tahun 2003 tentang Pemilihan Umum. Di dalam pasal 3 Undang-undang tersebut dinyatakan:

"Pemilu diselenggarakan untuk memilih DPR, DPD, DPRD

Provinsi, dan DPRD Kabupaten/Kota." 28

Selain itu, pemilu dalam negara demokratik merupakan mekanisme pemerintahan yang ditujukan untuk mempertahankan sistem demokratik-sekuleristik. Kenyataan ini tampak jelas dalam UU No. 12 tahun 2003 Tentang Pemilihan Umum Anggota DPR, DPD, dan DPRD, Bab I Ketentuan Umum, yang menyatakan:

"Pemilihan umum yang selanjutnya disebut Pemilu adalah sarana pelaksanaan kedaulatan rakyat dalam NKRI yang berdasarkan Pancasila dan UUD Negara Republik Indonesia Tahun 1945." 29

Lebih dari itu, di dalam undang-undang yang sama juga dinyatakan bahwa partai politik maupun perorangan tidak boleh mengkampanyekan materi-materi yang mempersoalkan dasar negara Pancasila dan Pembukaan UUD 1945. Dalam pasal 74 ayat (1) dinyatakan:

“Dalam kampanye pemilu dilarang mempersoalkan dasar negara Pancasila dan Pembukaan UUD 1945 dan Pembukaan UUD Negara Republik Indonesia Tahun 1945."

\footnotetext{
${ }^{27}$ Ibid. 6.

${ }^{28}$ Undang-Undang No. 12 Tahun 2003 pasal 5

${ }^{29}$ Ibid, pasal I
} 
Seperti yang telah dibahas dalam bab sebelumnya bahwa pemilu (musyawarah) sudah dilaksanakan sejak zaman Nabi ataupun pada masa khulafaur rasyidin, pelaksanaan prinsip musyawarah ini tidak mungkin dilakukan dengan cara melibatkan seluruh umat secara langsung, tetapi yang paling memungkinkan adalah seorang imam (pemimpin) bermusyawarah dengan umatnya melalui wakil-wakil mereka yang telah dipilih oleh mereka sendiri, mereka inilah yang disebut ahlul halli wal aqdi . Pada zaman sekarang tidak bias diketahui kelayakan mereka kecuali melalui proses penyeleksian dan pemilihan terlebih dahulu. ${ }^{30}$

Dengan demikian, pelaksanaan musyawarah yang dimaksud dan keterlibatan umat dalam pemerintahan serta keberlangsungan otoritas mereka dalam mengawasi pemimpin yang dipilihnya, mengharuskan adalanya pemilihan secara musyawarah. Oleh karena itu, pemilihan umum dapat didefinisikan secara bersamasama untuk memilih siapa yang dikehendaki mereka, sehingga adanya pemilihan umum adalah sesuatu yang dibenarkan secara syar'i dan bukan semata-mata sebuah system yang diadopsi dari luar Islam. ${ }^{31}$

Pemilihan umum yang diselenggarakan oleh KPU untuk memilih presiden dan wakil presiden sebagai kepala negara dan pemerintahan yang diajukan oleh partai politik sebagai pengusung hanya merupakan media untuk memberikan kebebasan kepada rakyat untuk memilih siapa yang layak menjadi pemimpinnya dan wakil-wakilnya dalam parlemen yang akan memperjuangkan aspirasi mereka.

30 Ibid., 12.

31 lbid. 
Jika muncul pertanyaan: "Apakah KPU yang ada di Indonesia saat ini ada dalam Islam?" maka pertanyaan ini dapat di jawab dari uraian yang telah penulis ulas pada bab-bab sebelumnya, dengan meninjau dari tugas dan wewenangnya KPU dan ahlul halii wal aqdi mempunyai berbagai kesamaan sehingga penulis menyamakan antara keduanya. Diantara kesamaan mereka antara lain:

1. Mengangkat khalifah (pemimpin).

2. Antara keduanya sama-sama dipilih oleh pemimpin, Ahlul Halii Wal Aqdi dipilih oleh khalifah sedangkan KPU dipilih oleh presiden.

3. Mereka dipilih dari proses penyeleksian yang ketat, dengan berbagai syarat yang telah penulis urai pada bab sebelumnya.

Berdasarkan alasan di atas penulis menyimpulkan bahwa KPU adalah lembaga negara yang identik dengan lembaga ahlul halli wal aqdi dalam pemerintahan Islam. Lembaga ahlul halli wal aqdi dalam sejarah pemerintahan Islam khususnya pada masa pemerintahan Khulafaur Rasyidin bisa disebut sebagai panitia penyelenggara pemilihan umum yang meiliki keanggotaan sangat terbatas dan anggota-anggotanya tersebut menurut Al-Mawardi harus memiliki syarat-syarat yang telah penulis bahas pada bab sebelumnya.

Selain sebagai panitia penyelenggara pemilihan khalifah, lembaga ahlul halli wal aqdi atau al-syura meiliki tugas dan kewengan untuk memberikan masukan kepada khalifah, sebagai lembaga yang menampung aspirasi masyarakat, melakukan controlling terhadap kebijakan-kebijakan pemerintah, membuat undang-undang sekaligus mempunyai hak untuk mebatasi jumlah kandidat yang akan menjadi pemimpin.

Jika melihat dari salah satu tugas dan kewengan lembaga ahlul halli wal aqdi yakni membatasi jumlah kandidat yang akan menjadi khalifah sekaligus melakukan seleksi, maka tugas tersebut 
sama dengan tugas KPU yang memiliki tugas dan kewengan untuk melakukan seleksi terhadap calon presiden dan wakil presiden calon peserta pemilu yang nantinya akan dipilih oleh rakyat secara langsung lewat pemilu. Setelah proses pemilihan dilakukan, lembaga Ahlul Halii Wal Aqdi melakukan baiat terhadap khalifah terpilih sedangkan KPU penetapannya dilakukan dalam musyawarah atau rapat pleno.

Jika melihat secara keseluruhan dengan perspektif fikih siyâsah mengenai tugas dan kewenangan KPU di dalam melakukan seleksi pasangan calon presiden dan wakil presiden peserta pemilu tidak bertentangan dengan prinsip atau ajaran Islam yang mengedepankan musyawarah dan keadilan sekaligus transparansi dalam melakukan tugas, selain itu KPU bisa disamakan dengan lembaga Ahlul Halii Wal Aqdi. Dimana lembaga tersebut berarti melonggrkan dan mengikat, yang memiliki kewenangan untuk memutuskan dan dengan kata lain, lembaga ahlul halli wal aqdi adalah lembaga perwkilan yang menampung dan menyalurkan aspirasi rakyat sekaligus lembaga yang memiliki tugas untuk menyelenggarakan pemilihan khalifah (pemimpin).

\section{Penutup}

Berdasarkan analisa masalah yang telah penulis lakukan, maka didapat suatu kesimpulan, antara lain:

Komisi Pemilihan Umum (KPU) adalah lembaga penyelengara pemilu yang berifat nasional, tetap dan mandiri. Pemilihan umum atau pemilu yang diselenggarakan oleh KPU adalah untuk memilih anggota DPR, DPRD, DPD, presiden dan wakil presiden merupakan sarana pelaksana kedaulatan rakyat yang dilaksanakan secara langsung, umum, bebas, rahasia, jujur dan adil dalam Negara kesatuan Republik Indonesia yang berdasarkan Pancasila dan Undang-Undang Dasar Republik Indonesia tahun 1945.

Jika melihat dari salah satu tugas dan kewengan lembaga ahlul halli wal aqdi yakni membatasi jumlah kandidat yang akan 
menjadi khalifah sekaligus melakukan seleksi, maka tugas tersebut sama dengan tugas KPU yang memiliki tugas dan kewengan untuk melakukan seleksi terhadap calon presiden dan wakil presiden calon peserta pemilu yang nantinya akan dipilih oleh rakyat secara langsung lewat pemilu. Jika melihat secara keseluruhan dengan perspektif fikih siyâsah mengenai tugas dan kewenangan KPU di dalam melakukan seleksi pasangan calon presiden dan wakil presiden peserta pemilu tidak bertentangan dengan prinsip atau ajaran Islam yang mengedepankan musyawarah dan keadilan sekaligus transparansi dalam melakukan tugas, selain itu KPU bisa disamakan dengan lembaga ahlul halli wal aqdi . Dimana lembaga tersebut berarti melonggrkan dan mengikat, yang memiliki kewenangan untuk memutuskan dan dengan kata lain, lembaga ahlul halli wal aqdi adalah lembaga perwkilan yang menampung dan menyalurkan aspirasi rakyat sekaligus lembaga yang memiliki tugas untuk menyelenggarakan pemilihan khalifah (pemimpin).

\section{Daftar Pustaka}

Adan, Hasanuddin Yusuf. "Kampanye Dalam Perspektif Islam", dalam http://www.kampanyedalamprespektifislam.com, diakses pada 15 April 2014.

Zaidan, Abdul Karim dkk. Pemilu dan Parpol dalam Perspektif Syariah. Bandung: Syaamil Cipta Media, 2003.

Fathoni, Ahmad. "Komisi Pemilihan Umum".

http://id.wikipedia.org/wiki/Komisi_Pemilihan_Umum

diakses pada Selasa 24 Desember 2013 pkl 14.20

Undang-Undang No. 12 Tahun 2003.

Undang-Undang Nomor 22 Tahun 2007.

Undang-Undang Nomor 42 Tahun 2008.

Undang-Undang Republik Indonesia Nomor 15 Tahun 2011. 
M. Zainuddin MZ

UU No. 10 Tahun 2008.

UU No. 15 Tahun 2008. 